\title{
Mini Review on the Dynamic Probiotic-Bacillus coagulans
}

\author{
Kavita R Pandey* \\ Guru Nanak Institute for research and development (GNIRD), G N Khalsa College, India
}

Submission: August 06, 2017; Published: September 20, 2017

*Corresponding author: Kavita R Pandey, Guru Nanak Institute for research and development (GNIRD), G N Khalsa College, India,

Email: kavita.v.dubey@gmail.com

\section{Abstract}

The health conscious consumers have started understanding and gravitating towards probiotic consumption for the rise in documented health benefits they impart on the hosts. Digestive well-being is the global obsession among the rapidly aging population. Amongst the many probiotic bacteria and yeasts available, Bacillus coagulans is one of the most robust spore forming probiotic which is in high demand by the commercial producers for several technological advantages. This mini review enlists the reported health effects exerted by this dynamic probiotic- B. coagulans and also commercial formulations containing them.

Keywords: Bacillus coagulans, Probiotics, Commercial production

\section{Introduction}

Health benefits imparted by probitoics and their roles in maintaining health and disease prevention has been an area of extensive research in the past few decades. Some of the commonly used probiotics include Lactobacillus rhamnosus, $L$. reuteri, Bacillus coagulans, E. coli Nissle 1917, some enterococci and yeasts like Saccharomyces boulardii etc. Pandey et al. [1] have reviewed the major health benefits (and their probable mechanisms of action) ranging from diarrhea to cancer prevention etc. One of the nastiest technological problems probiotic fermentation industries face is loss of viable cell count during harsh processing conditions. Spore forming Bacillus probiotics remain in huge demand due to their ability to withstand the stringent processing conditions. One of the sturdiest probiotics is B. coagulans.

\section{Bacillus coagulans}

Bacillus coagulans (discovered in 1930) was formerly known as Lactobacillus sporogenes. B. coagulans is a spore forming non-pathogenic gram positive bacteria that produces $\mathrm{L}(+)$ lactic acid homofermentatively. B. coagulans is a remarkably resilient probiotic that is able to withstand extreme conditions (like high temperatures, processing, stomach acids and bile) and is room temperature-stable for up to 3 years. Sporulation property makes B. coagulans the favorite of commercial probiotic producers. Various preparations of B. coagulans in powder, tablet and capsule forms exist in the market imparting several health benefits on the hosts like treatment of prevention of some diseased conditions (some are enlisted in Table 1).
Table 1: Health benefit.

\begin{tabular}{|c|c|}
\hline Health benefit & Reference \\
\hline Prevents muscle damage during exercise & Jäger et al.[6] \\
\hline Gastrointestinal disorders like IBS and IBD & Majeed et al. [8] \\
\hline $\begin{array}{l}\text { Different types of diarrhea like Antibitoic } \\
\text { associated and travellers diarrhea) }\end{array}$ & Majeed et al. [7] \\
\hline Colitis (induced by Clostridium difficile) & Fitzpatrick et al. [4] \\
\hline Cadmium and mercury poisoning & Jafarpour et al. [5] \\
\hline Hypercholesterolemia & Abhari et al. [2] \\
\hline $\begin{array}{l}\text { Gut functions improvement in elderly } \\
\text { population }\end{array}$ & Nyangale et al. [9] \\
\hline Treating rheumatoid arthritis & Abhari et al. [2] \\
\hline $\begin{array}{l}\text { Poultry (boosting immunity \& growth } \\
\text { enhancement) }\end{array}$ & Park et al. [11] \\
\hline Preventing bacterial vaginosis & Sudha et al.[12] \\
\hline Cancer prevention & Azimirad et al. [3] \\
\hline
\end{tabular}

\section{Global Probitoic Market}

The penetration of probiotics in the market is very high. Probiotic foods are available in grocery stores and supermarkets, while probiotic supplements are available in pharmacies and health food shops. Moreover, the increasing obsession of digestive wellbeing and preventive healthcare has accelerated the market growth. There is increase in number of probiotic ingredient suppliers who develop tailored strains of microorganisms for integrating with a diverse set of probiotics products. 


\section{Dynamic Probiotic for Commercial Producers}

The probiotic ingredients market is segmented on the basis of application into food \& beverage (dairy, bakery \& confectionery, meat \& cereals, etc), dietary supplements, and animal feed. The global probiotic market is dominated by players likeYakult (Japan), Dupont (Danisco), Ganeden (USA), Sabinsa (USA), BioGaia (Sweden), Nestle (Switzerland) etc. Asia-Pacific is the largest market for probiotic products and ingredients with Japan having accounted for a major share. The dietary supplement segment is projected to grow at the highest CAGR of $8.0 \%$ from 2015 to 2020 . Health effects exerted by any probiotic is strain specific. Some of the commercial formulations containing $B$. coagulans strains have been enlisted below Table 2 .

Table 2:Commercial probiotic formulations containing Bacillus coagulans.

\begin{tabular}{|c|c|c|}
\hline Product & Strain & Manufacturer \\
\hline Staimune & $\begin{array}{l}\text { B. coagulans } \\
\text { GBI- } 30,6086\end{array}$ & $\begin{array}{c}\text { Ganeden (USA) } \\
\text { https://www. } \\
\text { ganedenprobiotics.com/ } \\
\text { probiotic-news/news/ } \\
\text { ganeden-receives-fda- } \\
\text { gras-on-probiotic-derived- } \\
\text { immune-health-ingredient- } \\
\text { sta }\end{array}$ \\
\hline $\begin{array}{l}\text { Sporlac R } \\
\text { (for aphthous } \\
\text { stomatitis) }\end{array}$ & & $\begin{array}{c}\text { Sanzyme (Japan) } \\
\text { http://sporlac.com/ } \\
\text { prodsporlac-Ds.aspx } \\
\text { Suja Probiotics (USA) }\end{array}$ \\
\hline $\begin{array}{l}\text { Pineapple probiotic } \\
\text { enhanced water }\end{array}$ & & $\begin{array}{l}\text { https://www.sujajuice.com/ } \\
\text { products/pressed-probiotic- } \\
\text { waters/pineapple-lemon- } \\
\text { cayenne/ }\end{array}$ \\
\hline $\begin{array}{l}\text { Radical ranch } \\
\text { crunchy probiotic } \\
\text { kale }\end{array}$ & $\begin{array}{l}\text { B. coagulans } \\
\text { GBI-30 }\end{array}$ & $\begin{array}{c}\text { Brad's plant based } \\
\text { https://bradsplantbased. } \\
\text { com/shop/crunchy-kale/ } \\
\text { crunchy-kale-radical-ranch- } \\
\text { wprobiotics-12-pack/ }\end{array}$ \\
\hline $\begin{array}{l}\text { Enjoy Life Pancake+ } \\
\text { waffle mix }\end{array}$ & $\begin{array}{l}\text { B. coagulans } \\
\text { GBI-30 }\end{array}$ & $\begin{array}{c}\text { Enjoy } \\
\text { https://enjoylifefoods.com/ } \\
\text { our-food/baking-mixes/ } \\
\text { pancake-waffle-mix/ }\end{array}$ \\
\hline $\begin{array}{l}\text { Nutty delight } \\
\text { museli }\end{array}$ & $\begin{array}{l}\text { B.coagulans } \\
\text { SNZ } 1969\end{array}$ & $\begin{array}{c}\text { INDIA } \\
\text { https://www.probiotaevent. } \\
\text { com/wp-content/ } \\
\text { uploads/2017/02/Emma- } \\
\text { Schofield-Probiota-2017.pdf }\end{array}$ \\
\hline NurtureMe & B. coagulans & $\begin{array}{c}\text { Ganeden (USA) } \\
\text { https://nurturme.com/ }\end{array}$ \\
\hline proDURA & B. coagulans & $\begin{array}{c}\text { MayPro (Japan) } \\
\text { http://maypro.com/ } \\
\text { products/produra\#_ednref1 }\end{array}$ \\
\hline Lactospore & $\begin{array}{l}\text { B. coagulans } \\
\text { MTCC } 5856\end{array}$ & $\begin{array}{c}\text { Sabinsa (USA) } \\
\text { http://www.lactospore.com/ }\end{array}$ \\
\hline
\end{tabular}

\section{Conclusions}

B. coagulans strains need a further characterization to rule out the speculations like causative agent for infections in patients with catheters and leading to rejections in organ transplants etc. Another lacunae in B. coagulans research is lack of large scale human trials and uncertainty of dosage amounts due to scanty clinical data. There is a need to evaluate the survival of $B$. coagulans during manufacturing process and storage conditions [2-12].

\section{References}

1. Park JH, Kim IH (2015) The effects of the supplementation of Bacillus subtilis RX7 and B2A strains on the performance, blood profiles, intestinal Salmonella concentration, noxious gas emission, organ weight and breast meat quality of broiler challenged with Salmonella typhimurium. Journal of animal physiology and animal nutrition 99(2): 326-334.

2. Abhari K, Shekarforoush SS, Hosseinzadeh S, Nazifi S, Sajedianfard J (2015) The effects of prebiotic, probiotic and synbiotic diets containing Bacillus coagulans and inulin on serum lipid profile in the rat. Veterinary Science Development 5(2).

3. Abhari K, Shekarforoush SS, Hosseinzadeh S, Nazifi S, Sajedianfard J, et al. (2016) The effects of orally administered Bacillus coagulans and inulin on prevention and progression of rheumatoid arthritis in rats. Food \& nutrition research 60(1): 30876.

4. Azimirad M, Alebouyeh $M$, Naji $T$ (2017) Inhibition of Lipopolysaccharide-Induced Interleukin 8 in Human Adenocarcinoma Cell Line HT-29 by Spore Probiotics: B. coagulans and B. subtilis (natto). Probiotics and antimicrobial proteins 9(1): 56-63.

5. Fitzpatrick LR, Small JS, Greene WH, Karpa KD, Farmer S, et al. (2012) Bacillus coagulans GBI-30, 6086 limits the recurrence of Clostridium difficile-Induced colitis following vancomycin withdrawal in mice. Gut pathogens $4(1): 13$.

6. Jafarpour D, Shekarforoush SS, Ghaisari HR, Nazifi S, Sajedianfard J (2015) Impact of synbiotic diets including inulin, Bacillus coagulans and Lactobacillus plantarum on intestinal microbiota of rat exposed to cadmium and mercury. Veterinary Science Development 5(2).

7. Jäger R, Shields KA, Lowery RP, De Souza EO, Partl JM, et al. (2016) Probiotic Bacillus coagulans GBI-30, 6086 reduces exercise-induced muscle damage and increases recovery. PeerJ 4: e2276.

8. Majeed M, Nagabhushanam K, Natarajan S, Sivakumar A, Ali F, et al. (2016) Bacillus coagulans MTCC 5856 supplementation in the management of diarrhea predominant Irritable Bowel Syndrome: a double blind randomized placebo controlled pilot clinical study. Nutrition journal 15(1): 21.

9. Majeed M, Nagabhushanam K, Sankaran N, Vaidyanathan P, Arumugam S, et al. (2017) U.S. Patent No. 9,579,352. Washington, DC: U.S. Patent and Trademark Office.

10. Nyangale EP, Farmer S, Cash HA, Keller D, ChernoffD et al. (2015) Bacillus coagulans GBI-30, 6086 modulates Faecalibacteriumprausnitzii in older men and women. The Journal of nutrition 145(7): 1446-1452.

11. Pandey KR, Naik SR, Vakil BV (2015) Probiotics, prebiotics and synbiotics-a review. Journal of food science and technology 52(12): 7577-7587.

12. Sudha MR, Yelikar KA, Deshpande S (2012) Clinical Study of Bacilluscoagulans Unique IS-2 (ATCC PTA-11748) in the Treatment of Patients with Bacterial Vaginosis. Indian journal of microbiology 52(3): 396-399. 
This work is licensed under Creative Commons Attribution 4.0 Licens

DOI: 10.19080/JDVS.2017.03.555614
Your next submission with Juniper Publishers will reach you the below assets

- Quality Editorial service

- Swift Peer Review

- Reprints availability

- E-prints Service

- Manuscript Podcast for convenient understanding

- Global attainment for your research

- Manuscript accessibility in different formats

( Pdf, E-pub, Full Text, Audio)

- Unceasing customer service

Track the below URL for one-step submission https://juniperpublishers.com/online-submission.php 